$10-2016$

\title{
Book Review: An Inconvenient Genocide: Who Now Remembers the Armenians?
}

Ronald G. Suny

University of Michigan - Ann Arbor

Follow this and additional works at: https://digitalcommons.usf.edu/gsp

\section{Recommended Citation}

Suny, Ronald G. (2016) "Book Review: An Inconvenient Genocide: Who Now Remembers the Armenians?," Genocide Studies and Prevention: An International Journal: Vol. 10: Iss. 2: 144-146.

DOI:

http://dx.doi.org/10.5038/1911-9933.10.2.1418

Available at: https://digitalcommons.usf.edu/gsp/vol10/iss2/15

This Book Review is brought to you for free and open access by the Open Access Journals at Digital Commons @ University of South Florida. It has been accepted for inclusion in Genocide Studies and Prevention: An International Journal by an authorized editor of Digital Commons @ University of South Florida. For more information, please contact digitalcommons@usf.edu. 
Book Review: An Inconvenient Genocide: Who Now Remembers the Armenians?

\author{
Ronald G. Suny \\ University of Michigan \\ Ann Arbor, Michigan, USA
}

An Inconvenient Genocide: Who Now Remembers the Armenians?

Geoffrey Robertson

London, Biteback Publishing, 2015

300 pages; Price: $£ 20.00$

Reviewed by Ronald Grigor Suny, The University of Michigan; National Research University Higher School of Economics, St. Petersburg, Russia

About the time of the centennial of the mass deportations and murders that constituted the Armenian Genocide of 1915, that deliberately obscured and neglected crime against humanity had finally found a large number of champions. The official Turkish state campaign to deny that a genocide had taken place, and the persistence of diaspora Turks and a few pseudo-scholars defending the government's claims, were largely seen as groundless obfuscations. A cascade of serious scholarly books and articles appeared; the rich and famous, including a number of Kardashians, visited Armenia; and Pope Francis publicly acknowledged the genocide. With the publication of German, Austrian, Vatican, American, and other archival documents, as well as the work of honest Turkish and Kurdish historians, most people familiar with the facts accepted the record of what had happened to the Ottoman Armenians and Assyrians during World War I as indisputable.

One of the most prominent people to have taken up the project of rectifying public understanding of the tragedies of 1915 is the international lawyer Geoffrey Robertson, the author of at least fifteen books on issues of law, freedom, and justice. Born in Australia and today a barrister and law professor in Great Britain, Robertson has defended numerous people in free speech and expression cases and taken on risky cases, such as those of the novelist Salman Rushdie, the Canadian artist Rick Gibson, Wikileaks founder Julian Assange, and the boxer Mike Tyson. He has had his own television program in Australia and received the honor of an appointment as Queen's Counsel. In the Genocide's one hundredth anniversary year he worked with Amal Clooney before the European Court of Human Rights in the notorious case of a Turkish denialist, Doğu Perinçek.

In An Inconvenient Genocide Robertson provides a careful study of the legal issues surrounding crimes that might be considered genocide. While such state-initiated mass killings had occurred earlier in history, and in the twentieth century with the Herero and Nama in German Southwest Africa, the Armenians and Assyrians, and Jews, Roma, and others in the Holocaust, the Polish Jewish jurist Raphael Lemkin did not invent the word "genocide" and conceptualize the crime until mid-way through the Second World War. Not until the 1990s, Robertson writes, did the United Nations "deliver on the Nuremburg legacy, by setting up international courts to punish genocide in Rwanda and the Balkans," with the first verdict coming down (for Rwanda) in 1998. ${ }^{1}$ Significantly, the court clarified the language in the Genocide Convention of 1948 "deliberately inflicting on the group conditions of life calculated to bring about its physical destruction in whole or in part" to mean "methods of destruction by which the perpetrator does not immediately kill the members of the group but which, ultimately, seek their physical destruction." Thus, starvation, systematic expulsion from homes, and inadequate medical services directed against a targeted ethnoreligious people would constitute genocide. All of these practices were carried out on the Armenians.

After a brief history of the events and a discussion of the eyewitness, diplomatic, and archival evidence, Robertson notes that after the German government aided the escape of the Young Turk leaders, the successor government of the late Ottoman Empire held trials of perpetrators. In these

${ }^{1}$ Geoffrey Robertson, An Inconvenient Genocide: Who Now Remembers the Armenians? (London: Biteback Publishing, 2015$), 33$. 
precursors of the Nuremburg Trials, the accused were found guilty of crimes against humanity. "It is sad," writes Robertson, "that Turkey can never take pride in this moment of its history, and tends either to portray the liberals as 'quislings"' (in the words of a principal American denier) "or to see the trials as little more than a cunning attempt to gain an advantage at [the post-war] Versailles [Peace Conference]." ${ }^{2}$

Robertson's principal contribution to the discussion of the Armenian Genocide is his review of the law and the place of genocide in international jurisprudence. Within the larger rubric of crimes against humanity, genocide is a crime against an ethnic, national, racial, or religious group, distinct from the crimes of extermination or persecution against political or social groups (politicide or classicide). "[I]n effect, all genocides are crimes against humanity, but by no means do all crimes against humanity amount to genocide." 3 To be considered genocide destruction need not be total, and responsibility falls not only on who directly carried out killings but on those leaders, like the Ottoman government, that ordered deportations knowing "that the marches would kill - and were killing - most of those who marched." 4 Intention to commit genocide can be inferred from words and deeds, knowledge of consequences, and public statements.

Intention, however, is different from motivation. Whatever the reason behind deportation or killing - greed, fear, a sense of betrayal, religious conviction, race hatred, or as an element of warfare - the intention to destroy a group and prevent its collective reproduction is sufficient to convict someone of the crime of genocide. A government need not have a premeditated policy or a prior plan to commit genocide. "There is no doubt," Robertson makes clear, "that in 1915 the Ottoman government continued the deportations in the knowledge that many of the deportees would die, and that it passed laws and regulations that enabled it to seize their property on the pretense that it was 'abandoned' - that is, that they would not be allowed to return and reclaim it." ${ }^{5}$

Those who deny that a genocide took place have argued that the Armenians of Ottoman Anatolia were conspiring to rebel against the empire and that they constituted an existential threat to the government, the Turkish nation, and to Ottoman war effort against Russia and Britain. Historians, however, have concluded that no such insurrection was being planned or was even possible in the context of World War I. Most Ottoman Armenians were loyal to the empire, though they desperately and in vain hoped for reforms to improve their lives and protect them from the predations of Kurds. Tens of thousands of Armenian youth were mobilized and fought in the Ottoman Army until they were forcibly demobilized by their superiors, turned into work battalions, and eventually slaughtered. Even if Armenians had been an internal threat, the arguments of both officials and a few denialist scholars that "military necessity" required their removal would not hold up as a viable defense in international tribunals. "Necessity' in war can never justify the deliberate killing of civilians: if they are suspected of treason or loyalty to the enemy they may be detained or interned, or prosecuted, but not sent on marches from which they are expected not to return." 6

The stunning achievement of this book is that a sharp legal mind, carefully and systematically laying out irrefutably the argument that 1915 constituted a genocide, manages both to constrain his rage at the obscenity of denialism and allow the reader to feel the author's passion for justice. As fiercely as he exposes the lies of the deniers, Robertson opposes laws that would prohibit people from freely expressing such reprehensible and malicious views on genocide. Such expression should not be criminalized "unless there is an additionally proved intention to stir up race hatred or else a threat to public order or social cohesion." ${ }^{7}$ In 2005 the right-wing Turkish nationalist Doğu Perinçek deliberately declared in a public meeting in Lausanne that the Armenian Genocide was "an international lie." Swiss courts found him guilty of breaking a law against genocide denial, but

\footnotetext{
${ }^{2}$ Ibid., 85 .

${ }^{3}$ Ibid., 122.

${ }^{4}$ Ibid., 101.

${ }^{5}$ Ibid., 108

${ }^{6}$ Ibid., 117.

${ }^{7}$ Ibid., 208.
} 
the European Court of Human Rights in Strasbourg reversed the verdict and found that Perinçek's rights to free expression had been violated. Robertson defends Perinçek's right to speak but is appalled that the court went on to cast doubt on the Genocide itself by claiming the historical facts were difficult to ascertain and that denial was "part of a heated debate." ${ }^{\prime \prime}$ The case has been referred to the Chamber for review.

The present-day Republic of Turkey is the successor state of the Ottoman Empire, and because of its continued denial of the Genocide and its near century of appropriation of Armenian property and discrimination against Armenians within Turkey, "it has continued the original wrong." "Some form of recognition - apology, reparations, restoration of property and cultural monuments to the heirs of the original owners - Robertson argues, must be part of the settlement of claims against Turkey -- and against Germany for complicity in the deportations and massacres. There is right now a museum in Iğdır in eastern Turkey claiming that there were Armenian massacres of Muslims amounting to genocide as well as a permanent exhibition in Istanbul's military museum making the same argument. Perhaps one form of compensation might be to build a Persecution Museum in Istanbul, one that would acknowledge and illustrate the atrocities not only against Armenians and Assyrians but against Greeks, Alevis, Kurds, and others that continue to the present time. 